\title{
$\mathrm{RC}$ 部材中の軸方向鉄筋の座屈に関する実験的検討 ${ }^{\dagger}$
}

$$
\text { 井上 晋* 宮川豊 章* 藤 井 }
$$

\section{An Experimental Study on Buckling of Longitudinal Reinforcement in Reinforced Concrete Members}

by

\author{
Susumu InouE*, Toyoaki Mryagawa* and Manabu FujII*
}

In order to improve the ductility of reinforced concrete (RC) members, it is very effective to confine the concrete laterally in the compression zone of section by spirals or hoops. As for the mechanical properties of confined concrete, many researchers have conducted experimental and theoretical studies, and proposed different stress-strain relationships for confined concrete. In the large deformation zone after the maximum load, however, buckling of longitudinal reinforcement may occur in RC members even if they have an adequate amount of lateral confinement, and this leads to a significant reduction in the load carrying capacity. Therefore, it is important to investigate the effects of various factors on the buckling of longitudinal reinforcement in order to make clear the load carrying behaviors of $\mathrm{RC}$ members after the maximum load.

In this study, the effects of (i) spacing of lateral confinement (s), (ii) diameter of longitudinal bar (d), (iii) cover for lateral confinement (c) and (iv) the number of intervals having the length of $s(n)$ on the longitudinal strain at buckling of reinforcing bars were investigated by carrying out the uni-axial loading test on RC square column specimens.

Test results showed that the strain at buckling of longitudinal reinforcement became larger with a decrease in $s, c$ or $n$ and with an increase in $d$. The effect of $s$ became more significant when the $d$ -value became larger within the $s$-values selected in this study. On the other hand, the effect of $d$ was more remarkable when the $s$-value became smaller.

Key words : Buckling, Longitudinal reinforcement, Strain at buckling, Buckling made, Spacing of lateral confinement, Diameter of reinforcing bar

\section{1 まえがき}

地震荷重作用時にコンクリート構造物に十分な変形 性能を与えるための方策の一つとして，断面圧縮域の コンクリートをスパイラル筋やフープ筋を用いて横方 向に拘束することが挙げられる．これにより，軸方向 応力の作用下においてコンクリートを 3 軸応力状態と し, 圧縮強度 ·変形能力を著しく増加させることが可 能となるばかりでなく，部材中の軸方向圧縮鉄筋の早 期座屈を防止・抑制できることは周知の事実である.

これらのうち, コンクリートそのものの圧縮じん性改 善効果については今まで数多くの研究がなされてきて おり，横拘束コンクリートの応力ーひずみモデルも数 多く提案されている．しかしながら，軸方向鉄筋の座 屈防止・抑制効果については, 実験方法や座屈時の判 定法などの問題点から不明確な点が多く，また，横拘 束筋を配置していても，大変形領域では圧縮側鉄筋の 座屈が生じ，これにともなって耐荷力が急激に低下す るため, 部材の終局時が主筋の座屈によって決定され
る場合が多い. したがって，大変形領域での $\mathrm{RC}$ 部 材の挙動を正確に把握するためには, 軸方向鉄筋の座 屈に及ぼす種々要因の影響を明らかにしておくことが 必要であると考えられる.

本研究では, RC 角柱供試体に対して一軸圧縮試験 を実施し， RC 部材中の軸方向鉄筋の座屈時の判定法 について検討するとともに，座屈時の供試体の平均ひ ずみに及ぼす各種要因の影響を検討した。

\section{$2 \cdot 1$ 実験要因}

\section{2 実 験 概 要}

$\mathrm{RC}$ 部材中の軸方向鉄筋の座屈に影響を及ぼすと考 えられる要因は多数あるが, 本研究では, (1) 横拘束 筋配置間隔 $s$, (2) 軸方向鉄筋径 $d,(3)$ 横拘束筋に対 するかぶり $c$ および $(4)$ 間隔 $s$ で横拘束筋を配置した 区間数 $n$ の 4 つの要因の影響を検討することとした. これらのうち，(1)，(2) は従来よりその影響が大きい と考えられているものであり，(1)については $4 \mathrm{~cm}$ お よび $8 \mathrm{~cm}$ の 2 種類，(2) については $10 \mathrm{mm（D10を}$

$†$ 原稿受理 平成 2 年11月29日 Received Oct. 29, 1990

* 正 会 員 京都大学工学部，京都市左京区吉田本町, Faculty of Engineering, Kyoto University, Yoshida-honmachi, Sakyo-ku, Kyoto 


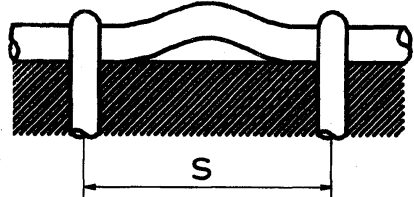

(a) Single tie interval $(\mathrm{n}=1)$

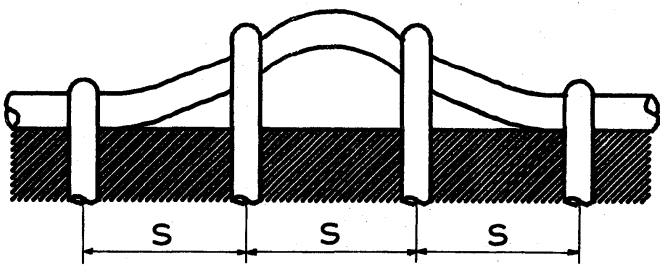

(b) Spanning three tie intervals $(n=3)$

Fig. 1. Shapes of buckled bars.

使用）および $13 \mathrm{~mm}$ （D13 を使用）の 2 種類を選定 した.（3）については，横拘束コンクリートそのもの の圧縮じん性を改善するためには, 横拘束筋のかぶり をできるだけ少なくした方がよいことが指摘されてい るが，ここでは主として軸方向鉄筋の座屈時ひずみに 及ぼすかぶりコンクリートの影響を考察することを目 的として，0（かぶりなし）, $5 \mathrm{~mm}, 10 \mathrm{~mm}$ の 3 種 類を選定した．本研究では，座屈が生じる区間をあら かじめ決めておくことを目的として，上記諸量を有す る区間を供試体中央部に 1 区間設け，それ以外の部分

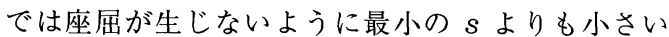
$3 \mathrm{~cm}$ 間隔で横拘束筋を配置した。しかし，軸方向鉄 筋の座屈は Fig. 1 (a) に示すような横拘束筋を配置し た 1 区間で生じるとは限らず，Fig. 1(b)に示すように
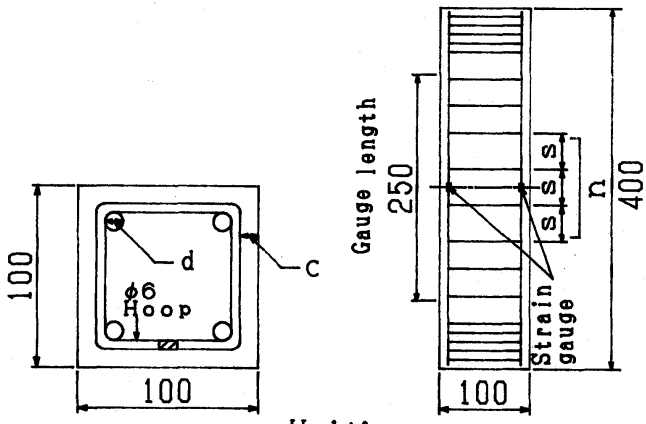

Un i $t: \mathbf{m m}$

Fig. 2. Dimensions of test specimen.

Table I. Mechanical properties of reinforcing bars.

\begin{tabular}{c|c|c}
\hline Kind of bars & $\begin{array}{c}\text { Yield strength } \\
f_{s y}\left(\mathrm{kgf} / \mathrm{cm}^{2}\right)\end{array}$ & $\begin{array}{c}\text { Tensile strength } \\
f_{s u}\left(\mathrm{kgf} / \mathrm{cm}^{2}\right)\end{array}$ \\
\hline$\phi 6$ & 3120 & 4320 \\
\hline D10 & 4000 & 5750 \\
\hline D13 & 3550 & 5080 \\
\hline
\end{tabular}

多区間にわたって生じ得ることが指摘されておりり，ど のような要因の組合せのもとにこのような座屈モード が生じるかを検討すること，また，弱点となる区間が 1 区間のみの場合と多数ある場合の差異を検討するこ とを目的として(4)の要因を設定し, 間隔 $s$ で横拘束 筋を配置する区間数 $n$ を 1 としたものと 3 としたも のの 2 種類の供試体を作製した。

\section{$2 \cdot 2$ 供試体}

供試体には，Fig. 2 に示すように，断面内に 4 本の 軸方向鉄筋を配置した $10 \times 10 \times 40 \mathrm{~cm}$ の RC 角柱を

Table II. Details of test variables and results of tests.

\begin{tabular}{|c|c|c|c|c|c|c|c|}
\hline Specimen & $\begin{array}{c}S \\
(\mathrm{~cm})\end{array}$ & $\begin{array}{c}d \\
(\mathrm{~mm})\end{array}$ & $\begin{array}{c}c \\
(\mathrm{~mm})\end{array}$ & $n$ & $\begin{array}{l}\text { Buckling } \\
\text { mode }\end{array}$ & $\begin{array}{c}\text { Buckling } \\
\text { length } \\
l_{k} \\
(\mathrm{~cm})\end{array}$ & $\begin{array}{c}\text { Strain at } \\
\text { buckling } \\
\varepsilon_{b} \\
\left(\times 10^{-6}\right)\end{array}$ \\
\hline No. 1-A & 4 & 10 & 0 & 1 & (4) & 4.5 & 9624 \\
\hline B & 4 & 10 & 0 & 1 & - & - & - \\
\hline No. 2-A & 8 & 10 & 0 & 1 & (1) & 4.0 & 6035 \\
\hline B & 8 & 10 & 0 & 1 & (1) & 4.0 & 7095 \\
\hline No. $3-\mathrm{A}$ & 4 & 10 & 0 & 3 & (5) & 9.0 & 5449 \\
\hline B & 4 & 10 & 0 & 3 & - & - & - \\
\hline No. $4-\mathrm{A}$ & 8 & 10 & 0 & 3 & (1) & 4.0 & 5171 \\
\hline B & 8 & 10 & 0 & 3 & (1) & 4.0 & 4978 \\
\hline No. $5-\mathrm{A}$ & 4 & 10 & 5 & 1 & (2) & 4.0 & 8695 \\
\hline B & 4 & 10 & 5 & 1 & (2) & 4.0 & 11281 \\
\hline No. 6-A & 8 & 10 & 5 & 1 & (1) & 4.0. & 7743 \\
\hline B & 8 & 10 & 5 & 1 & (1) & 4.0 & 6436 \\
\hline No. 7-A & 4 & 10 & 5 & 3 & (2) & 4.0 & 9702 \\
\hline B & 4 & 10 & 5 & 3 & (1) & 2.0 & 7239 \\
\hline No. $8-\mathrm{A}$ & 8 & 10 & 5 & 3 & (1) & 4.0 & 4667 \\
\hline B & 8 & 10 & 5 & 3 & (1) & 4.0 & 6538 \\
\hline No. 9-A & 4 & 10 & 10 & 1 & (3) & 8.0 & 7475 \\
\hline B & 4 & 10 & 10 & 1 & (2) & 4.0 & 8635 \\
\hline No. $10-\mathrm{A}$ & 8 & 10 & 10 & 1 & (1) & 4.0 & 5881 \\
\hline B & 8 & 10 & 10 & 1 & (1) & 4.0 & 5152 \\
\hline No. 11-A & 4 & 10 & 10 & 3 & (2) & 4.0 & 8463 \\
\hline B & 4 & 10 & 10 & 3 & (1) & 2.0 & 8428 \\
\hline No. $12-\mathrm{A}$ & 8 & 10 & 10 & 3 & (1) & 4.0 & 5553 \\
\hline B & 8 & 10 & 10 & 3 & (1) & 4.0 & 4810 \\
\hline No. 13-A & 4 & 13 & 0 & 1 & - & - & - \\
\hline B & 4 & 13 & 0 & 1 & - & - & - \\
\hline No. $14-\mathrm{A}$ & 8 & 13 & 0 & 1 & (2) & 3.0 & 7459 \\
\hline B & 8 & 13 & 0 & 1 & - & - & - \\
\hline No. $15-\mathrm{A}$ & 4 & 13 & 0 & 3 & (4) & 6.0 & 9173 \\
\hline B & 4 & 13 & 0 & 3 & - & - & - \\
\hline No. $16-\mathrm{A}$ & 8 & 13 & 0 & 3 & - & - & - \\
\hline B & 8 & 13 & 0 & 3 & - & - & - \\
\hline No. $17-\mathrm{A}$ & 4 & 13 & 5 & 1 & (2) & 3.0 & 13354 \\
\hline B & 4 & 13 & 5 & 1 & (5) & 9.0 & 18347 \\
\hline No. $18-\mathrm{A}$ & 8 & 13 & 5 & 1 & (1) & 4.0 & 6859 \\
\hline B & 8 & 13 & 5 & 1 & (1) & 4.0 & 5522 \\
\hline No. $19-\mathrm{A}$ & 4 & 13 & 5 & 3 & 一 & - & - \\
\hline B & 4 & 13 & 5 & 3 & (4) & 6.0 & 15230 \\
\hline No. $20-\mathrm{A}$ & 8 & 13 & 5 & 3 & - & - & - \\
\hline B & 8 & 13 & 5 & 3 & (1) & 4.0 & 9278 \\
\hline No. $21-\mathrm{A}$ & 4 & 13 & 10 & 1 & (2) & 4.0 & 16511 \\
\hline B & 4 & 13 & 10 & 1 & (2) & 4.0 & 11949 \\
\hline No. $22-\mathrm{A}$ & 8 & 13 & 10 & 1 & (2) & 8.0 & 7323 \\
\hline B & 8 & 13 & 10 & 1 & (2) & 8.0 & 5432 \\
\hline No. $23-\mathrm{A}$ & 4 & 13 & 10 & 3 & - & - & - \\
\hline B & 4 & 13 & 10 & 3 & (2) & 4.0 & 10636 \\
\hline No. 24-A & 8 & 13 & 10 & 3 & (1) & 4.0 & 5028 \\
\hline B & 8 & 13 & 10 & 3 & (2) & 8.0 & 4815 \\
\hline
\end{tabular}

* The mark of - indicates the specimens in which the buckling of longitudinal bar occurred outside of the gauge length or concrete at the end zone outside of the gauge length deteriorated earlier. 


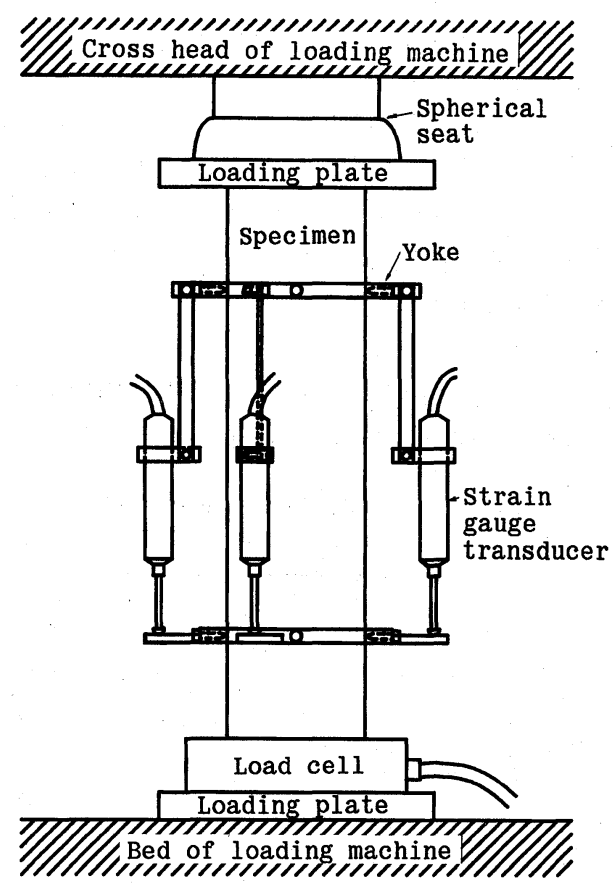

Fig. 3. Loading and measuring apparatus.

用いた．軸方向鉄筋には SD30 の異形鉄筋 D10 およ びD13を，また，横拘束筋には $\phi 6 \mathrm{~mm}$ の丸鋼を突合 せ溶接したものを用いた。これらの機械的性質を Table Iに示す。なお，コンクリートの設計圧縮強度 は要因に関係なくいずれも $300 \mathrm{kgf} / \mathrm{cm}^{2}(W / C$ $=60 \%, s / a=49 \%)$ とした.

供試体は, 前述の要因の組合せにより 24 種類のも のについて各 2 体ずつ，計 48 体作製した。 これらの 詳細を Table II に示す.

\section{$2 \cdot 3$ 載荷方法および測定項目}

載荷は 200 tonf のアムスラー型耐圧試験機を用い て行い，供試体の軸方向平均ひずみを，Fig. 3 に示す ように，容量 $10 \mathrm{~mm}$ の変位計を 4 個用いて相対する 2 面の対称位置で測定した．供試体の座屈時ひずみは, その座屈領域の大きさやひずみ測定の検長により左右 されることが指摘されて扔り，結果を比較するために は検長を一定にしておく必要があると思われる。そこ で, 本研究では，考えられる最大の破壊（座屈）領域 を包含することを目的とし，検長をすべての供試体で $250 \mathrm{~mm}$ とした，また，供試体によっては，座屈が生 ビると予想される区間内の軸方向鉄筋の外側に抵抗線 ひずみゲージ（検長 $2 \mathrm{~mm}$ ）を貼付し，ひずみを測定 することにより座屈時の判定の参考資料とした。

\section{3 試験結果および考察}

\section{$3 \cdot 1$ 座屈時の決定法}

$\mathrm{RC}$ 部材中の軸方向鉄筋の座屈に関する研究を行う 上で最も問題となる点は，座屈時をいかに定義するか
ということである。これは，主として，実部材中では かぶりコンクリートの存在により軸方向鉄筋の屈曲を 目視できないこと，軸方向鉄筋の横方向へのはらみ出 しの程度と耐力低下の関係が明確でないこと，一定間 隔で横拘束筋を配置した供試体においては座屈が生じ る区間を予測しにくいこと，等に起因するものである。 これらの理由により, 座屈時の定義法は研究者によっ て異なっており，統一的な考え方は確立されていない が，現時点では，丸山らが行っているように，軸方向 鉄筋の内側と外側に貼付したひずみゲージの読みに基

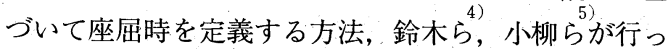
ているように，供試体の荷重-軸方向ひずみ関係を求 め, これらの耐力下降勾配や変曲点から座屈時を定義 する方法が挙げられる。これらのうち，前者の方法は 座屈開始という現象を局部的な現象としてとらえる場 合は有効であると考えられるが，座屈が生じる区間を 予測してゲージを貼付する必要があり，本研究のよう に，ゲージを貼付した区間以外で座屈した供試体があ る場合には不適当と考えられる．したがって，本研究 では，座屈の開始・進行を部材レベルの全体的挙動と してとらえることを考え，後者の方法を参考にして以 下のように座屈時を決定した.

一般に, 軸方向鉄筋の座屈はかぶりコンクリートの 圧潰・はく落後に生じると考えるのが妥当である．し たがって, 座屈開始時のひずみの值は横拘束コンクリ 一トそのものの最大応力時，すなわち供試体の最大耐 力時のひずみより大きな值となると考えられる. 一方,

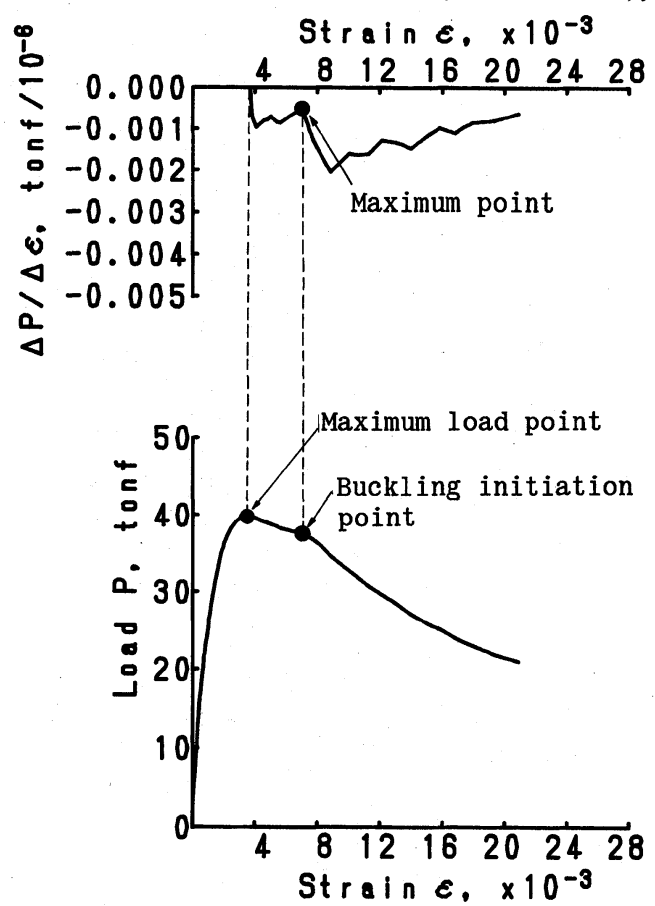

Fig. 4. Definition of strain at buckling. 
ひずみゲージによる鉄筋の外側ひずみと載荷荷重との 関係においては，供試体軸方向ひずみが増加している にもかかわらず，鉄筋ひずみが減少し始める点，すな わち鉄筋ひずみの值が最大となる点が存在し，この時 点においては座屈が既に生じているものと推察される. したがって, 実際の座屈開始点は, 最大荷重時の供試 体軸方向ひずみと鉄筋の外側ひずみが最大となる点に 対応する供試体軸方向ひずみの中間領域に存在すると 考えられる. そこで, 本研究では, その範囲内で実験 結果より横軸に供試体軸方向ひずみ, 縦軸に荷重-ひ ずみ曲線の勾配 $(\Delta P / \Delta \varepsilon)$ をとり, Fig. 4 のような グラフを描いた. このグラフにおいて, 最大荷重到達 直後荷重一ひずみ曲線の勾配が負に転じ, 急激に減少 （絶対值は増加）し始めるが, これはかぶりコンクリ ートが圧潰, はく落したことによるところが大きいと 考えられる. その後, 勾配は極小值を経験した後再び 徐々に増加または横這いする傾向を示す。これは, か ぶりコンクリートの圧潰, はく落が一段落したためと 考えられる. しかし, その増加も極大点を迎え, 再び 勾配が急激に減少し始める. 本研究においては, この 極大点時のひずみを座屈開始時ひずみと定義した.こ れは横拘束コンクリートそのものの応力低下勾配を一 定と仮定した場合, この急激な勾配の変化は軸方向鉄 筋の座屈のために起こった耐力低下に起因して生じた ものだと考えられるからである。

\section{$3 \cdot 2$ 座屈形式}

供試体で観察された座屈形式を模式図的にFig. 5 に 示す。また, 各供試体の座屈形式およびそれより計算 される有効座屈長を Table II に示す.なお, 有効座 屈長は, Fig. 5 の (1), (4)のように両端が固定されて いたと考えられる場合は座屈が生じた区間長の $1 / 2$ に，また，(2)，(3)，(5)のように端部に横方向の変位 が生じている場合には座屈が生じた区間長に等しいも のとして計算した。

軸方向鉄筋にD10を用いた供試体 $(d=10 \mathrm{~mm})$ で は, 横拘束筋配置間隔 $s=8 \mathrm{~cm}$ の場合は例外なく図 中の (1)の座屈形式を示した. これに対し $s=4 \mathrm{~cm}$ の ものは (2) の座屈形式を示すものが多く, 座屈形式よ り計算されるこれらの供試体の座屈長は， $s$ に関係な くほほ $4 \mathrm{~cm}$ となる.なお， $s=4 \mathrm{~cm}$ の場合は端部に

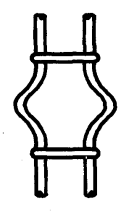

(1)

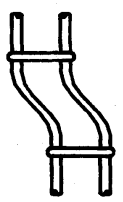

(2)

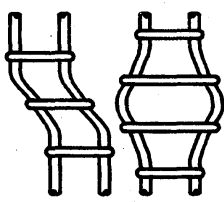

(3)

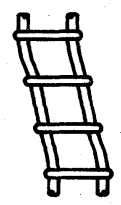

(5)
Fig. 5. Schema of buckling mode observed in the specimens.
横方向の変位が生じており, 両端が固定されている場 合の座屈発生区間長を有効座屈長の 2 倍とした場合に は座屈発生区問長は $8 \mathrm{~cm}$ となる。このことは, 鈴木 らも指摘しているように, $s$ が小さい範囲 (本研究の 場合 $s / D \leqq 0.8, D$ : 供試体断面最小寸法 $=10 \mathrm{~cm}$ ) で は, 軸方向鉄筋の座屈は $s$ に関係なくほほ $D$ に等し い区間で生じる（有効座屈長は $D / 2$ となる）ことを 示している.

一方，軸方向鉄筋に D 13 を用いた供試体（ $d=13$ $\mathrm{mm}$ ) では, 径の増加により座屈が生じにくくなるた め, 軸方向ひずみ測定区間外で横拘束コンクリートそ のものが早期に劣化するものが多く認められた．した がって, これらの供試体 (Table II 中一印で示した もの）は考察の対象外とした. それ以外の供試体の座 屈形式は, $s=8 \mathrm{~cm}$ ののでは (1) と (2) の座屈形式 が混在し，D10を用いたものと若干異なった傾向を 示している. また, $s=4 \mathrm{~cm}$ とした供試体では D10 を用いたものと同様に (2) の座屈形式を示すものが多 かったが, 座屈が 2 補強区間以上で生じているもの (Fig. 5 の (3), (4), (5) が D10に較べて若干多くみら れ, これらより, 有効座屈長は D10の場合と較べ大 きくなるものと推察される.

また, $n=3$ の供試体においても座屈が 2 補強区間 以上にわたって生じているものは少なく，3 区間の内 のどこかで (1) あるいは (2) の座屈形式を示すものが多 くみられ, $s=8 \mathrm{~cm}$ の場合には複数の区間で (1)の座 屈形式を示しているものもあった. 一方, $n=1$ の供 試体において, 座屈区間が 2 補強区間以上にわたって いるものがあるが, これらは $s=4 \mathrm{~cm}$ の場合に限ら れており, 中央区間以外の領域の横拘束筋配置間隔が $3 \mathrm{~cm}$ であることから，供試体作製時の不確実さによ るところが大きいと考えられる.

\section{$3 \cdot 3$ 座屈時の供試体軸方向ひずみに及ぼす各要因 の影響}

Fig. 6 に荷重-供試体軸方向ひずみ関係の一例を示 す.これらの図より $3 \cdot 1$ 節で述べた方法で定義した

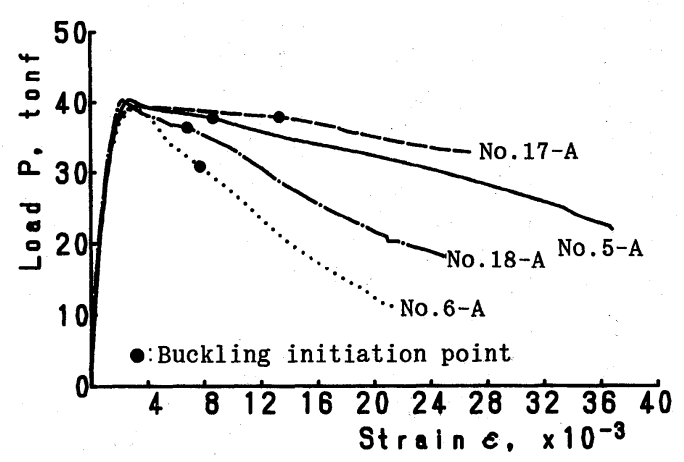

Fig. 6. Examples of load-longitudinal strain relationship. 
軸方向鉄筋座屈時ひずみの值 $\left(\varepsilon_{b}\right)$ をそれぞれの供試 体について求め, 以下の要因の影響について検討した。 この場合, 座屈時ひずみは供試体中央 $250 \mathrm{~mm}$ を検長 とした平均ひずみに基づいて決定しているため，例え ば, $n=1, n=3$ で異なってくる隣接領域 $(3 \mathrm{~cm}$ 間 隔で横拘束筋を配置した領域）の長さの影響を分離し て考察するのは困難である：したがって，ここでは 4 つの要因の内の 3 つが同じ供試体間では，隣接領域が 及ぼす影響を一定とみなして，残り1つの要因による 影響を検討することとした，ただし，考察に際して同 じ供試体が 2 体ある場合は，座屈時ひずみの值として その平均值を用い，軸方向ひずみ測定区間外で破壊し た供試体については考察の対象外とした.

$3 \cdot 3 \cdot 1$ 横拘束筋配置間隔 $s$ Fig. 7 に横拘束筋 配置間隔の影響について調べたものを示す．グラフは 全体的に右下がりの傾向を示し，横拘束配置間隔が小 さいほど座屈時ひずみが大きくなることが明白にうか がえる，さらに，軸方向鉄筋にD10を用いた供試体 $(d=10 \mathrm{~mm})$ においては， $c=0, n=3$ の場合を除き， その減少率は他の要因に関係なくほとんど一定である とみることができる。一方，D13 を用いた供試体（d $=13 \mathrm{~mm})$ に打いては， $n=1$ と 3 の場合で值は異な るものの, 同一の $n$ ではかぶり $c$ に関係なくその減 少率がほぼ等しい。また，この減少率の值は $d$ によ り異なり， $d=10 \mathrm{~mm}$ の場合は $n, c$ に関係なくおよ そ $730 \mu / \mathrm{cm}$ となっているのに対し， $d=13 \mathrm{~mm}$ の場 合は $n=1$ の場合で約 $2000 \mu / \mathrm{cm}, n=3$ の場合で約 $1500 \mu / \mathrm{cm}$ となっている.これらのことから, 軸方 向鉄筋径が大きいほど座屈時ひずみは大きくなるもの の, 逆に, 本研究で選定した $s=4 \sim 8 \mathrm{~cm}$ という横拘 束筋配置間隔内では，軸方向鉄筋径が大きいほど横拘 束筋配置間隔によって受ける影響が大きくなると考え
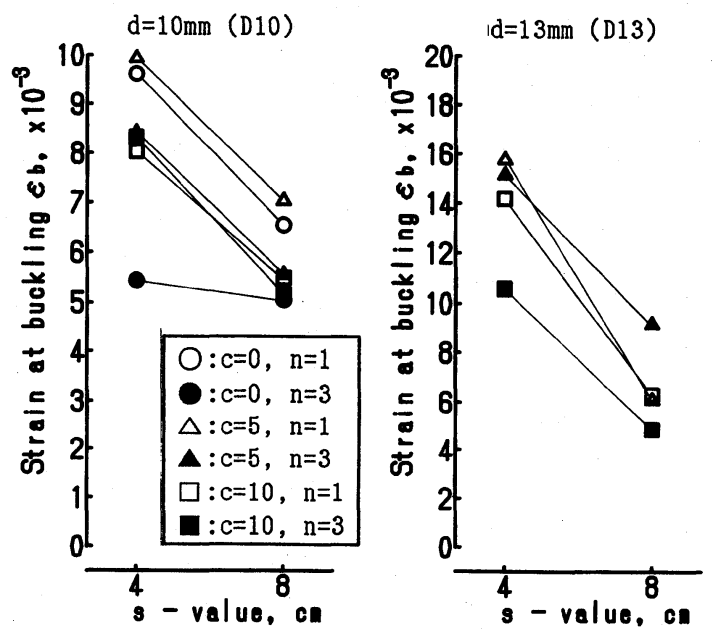

Fig. 7. The effect of spacing of lateral confinement $(s)$
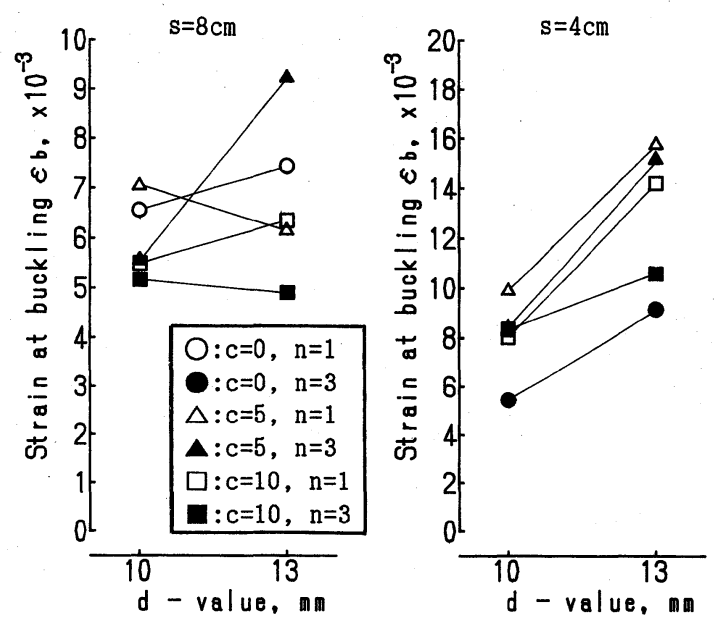

Fig. 8. The effect of diameter of longitudinal bar $(d)$.

ることができる．また，横拘束筋配置間隔がある值以 上に大きくなった場合 $(s / D \geqq 0.7)$, 供試体の軸方向 鉄筋の座屈時ひずみはコンクリートの最大応力時ひず み（約 $2000 \mu ）$ とほぼ等しく，sによってほとんど 変化しないということが従来の研究で報告されている が，本研究で選定したように横拘束筋間隔が比較的小 さい場合には，軸方向鉄筋座屈時ひずみは横拘束筋配 置間隔の影響を大きく受けると考えられる.

$3 \cdot 3 \cdot 2$ 軸方向鉄筋径 $d$ 軸方向鉄筋の影響につ いて調べたものを Fig. 8 に示す. $s=4 \mathrm{~cm}$ の場合, 傾きに若干違いはあるものの，全般的に右上がり，す なわち軸方向鉄筋径が大きいほど座屈時ひずみが大き くなる傾向を示す.一方， $s=8 \mathrm{~cm}$ の場合は，同様 の傾向を示すものの，その傾きが $s=4 \mathrm{~cm}$ の場合と 較べてかなり小さく，また，D10 と D13 でほとんど 差がないものもみられる．これらのことから， $s=8$ $\mathrm{cm}$ の場合のように， $s$ がある程度以上大きくなると 軸方向鉄筋座屈時ひずみがその軸方向鉄筋の径によっ て受ける影響は小さくなり，逆に， $s=4 \mathrm{~cm}$ という 小さな横拘束筋配置間隔ではその影響が大きくなると いうことができる.

$3 \cdot 3 \cdot 3$ かぶり $c \quad$ Fig. 9 は横拘束筋に対するか ぶりの影響について示したものである.ばらつきが多 く，また，試験区間内で座屈しなかった供試体もある ため，的確な判断を下すことは困難であるが， $d=10$ $\mathrm{mm}, s=4 \mathrm{~cm}, n=3$ および $d=13 \mathrm{~mm}, s=4 \mathrm{~cm}$, $n=3$ の場合を除き, $c=0$ と $5 \mathrm{~mm}$ では, 両者で座屈 時ひずみに大差はない.一方， $c=5 \mathrm{~mm}$ と $10 \mathrm{~mm}$ で 比較した場合，後者の座屈時ひずみが小さくなる傾向 がうかがえる. 本研究に用いた供試体においては, 軸 方向鉄筋の座屈はかぶりコンクリートが圧潰, はく落 した後に生じており，このことから考えると，かぶり 

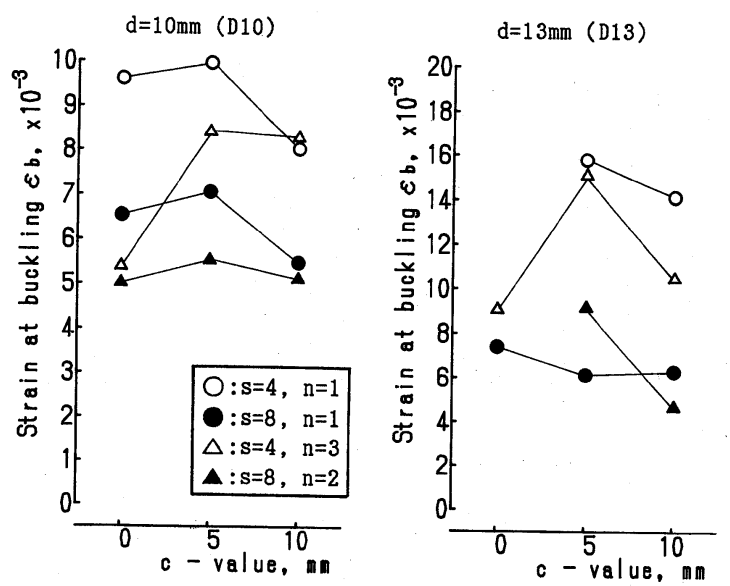

Fig. 9. The effect of cover for lateral confinement $(c)$.
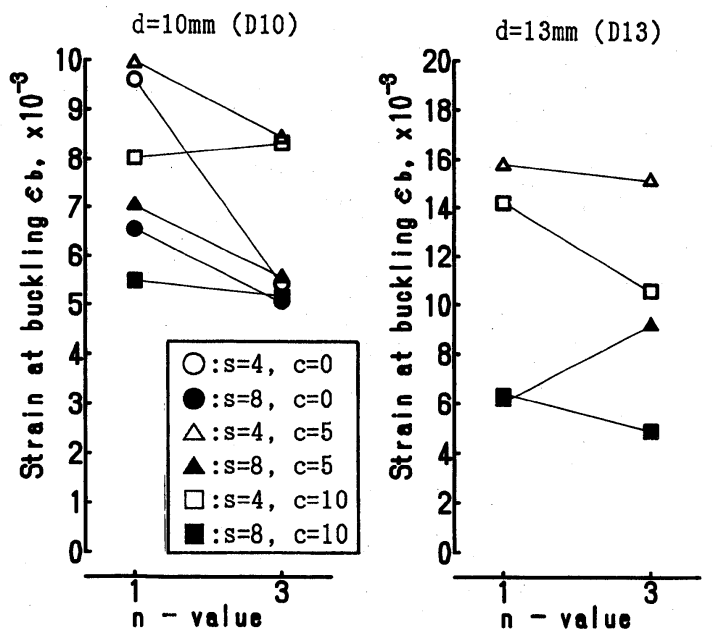

Fig. 10. The effect of the number of intervals having the length of $s(n)$.

$c$ が座屈時ひずみに及ぼす影響は少ないと考えられ， 上述のような傾向はむしろ $s / D^{\prime}\left(D^{\prime}:\right.$ 横拘束筋の一 辺の長さ）の大小に起因して生じたものと思われる.

$3 \cdot 3 \cdot 4$ 区間数 $n$ Fig. 10 に区間数 $n$ の影響を調 べたものを示す．この図より， $d=10,13 \mathrm{~mm}$ のいず れの場合も一つの例外を除き， $n=3$ の供試体の方が $n=1$ の供試体よりも座屈時ひずみが小さくなる傾向 を示している. $n=1$ と $n=3$ では検長内に含まれる $3 \mathrm{~cm}$ 間隔で横拘束筋を配置した領域の長さが異なり, この影響が含まれていると考えられるが， $n=3 て ゙ は ，$ コンクリートの圧潰, はく落領域が $n=1$ に較べて大 きく，横拘束コンクリートそのものの耐力低下が早期 に起こり，これに起因して座屈時ひずみが小さくなっ
たものと思われる.

\author{
4 結 論
}

本研究においては， RC 角柱供試体の軸方向鉄筋座 屈時ひずみに及ぼす種々要因の影響を一軸圧縮試験を 実施することにより検討した，得られた結論は以下の ようである。

（1）軸方向鉄筋座屈時ひずみを求める方法の一つと して，供試体の最大耐力到達以降の荷重一ひずみ曲線 の勾配 $(\Delta P / \Delta \varepsilon)$ と供試体軸方向ひずみ $(\varepsilon)$ の関 係から，その極大点のひずみにより座屈時ひずみを定 義することが可能である.

(2) 軸方向鉄筋の座屈形式は, 横拘束筋配置間隔 $s$ が $4 \mathrm{~cm}$ と $8 \mathrm{~cm}$ の場合で異なることが多く，また， 座屈形式より計算される有効座屈長は, 軸方向鉄筋に D13を用いたものの方が D10を用いたものよりも若 干大きくなる.

（3）横拘束筋配置間隔 $s$ が小さいほど供試体の軸 方向鉄筋座屈時ひずみは大きくなり, 本研究で選定し た横拘束筋配置間隔内では，軸方向鉄筋径 $d$ が大き いほど横拘束筋配置間隔によって受ける影響は大きく なる。

（4）軸方向鉄筋径 $d$ が大きくなるほど座屈時ひず みは大きくなり, 横拘束筋配置間隔が小さい場合にそ の傾向は顕著となる。

（5） 横拘束筋に対するかぶり c が大きくなるほど, また, 間隔 $s$ で横拘束筋を配置した区間数 $n$ が多く なるほど軸方向鉄筋座屈時ひずみは小さくなる傾向が あるが，横拘束筋配置間隔 $s$ や軸方向鉄筋径 $d$ に較 べてその影響は小さく, 本研究のように検長内に間隔 の異なる横拘束筋配置区間を有する場合は，それによ る影響も含めて今後の検討が必要である.

(平成 2 年 6 月 5 日 土木学会関西支部年次学術講演会にて講演)

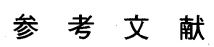

1 ) 井上 晋, 服部篤史, 宮川豊章, 藤井 学, 小林和夫, セメント・コンクリート論文集，43，340 (1989).

2 ) C. F. Scribner, ACI Journal, 83, 966 (1986).

3）丸山久一, 趙 唯堅, 清水敬二, コンクリート構造物の じん性と配筋方法に関するシンポジウム論文集, p. 47 (1990).

4 ）鈴木計夫, 中塚 佶, 長田省作, 井上和政, コンクリー 卜工学年次論文報告集, 9-2，151（1987）.

5 ) 小柳 洽, 六郷恵哲, 山本智志, 近藤吉信, 土木学会第 44回年次学術講演会概要集，第 5 部， p. 502 (1989). 